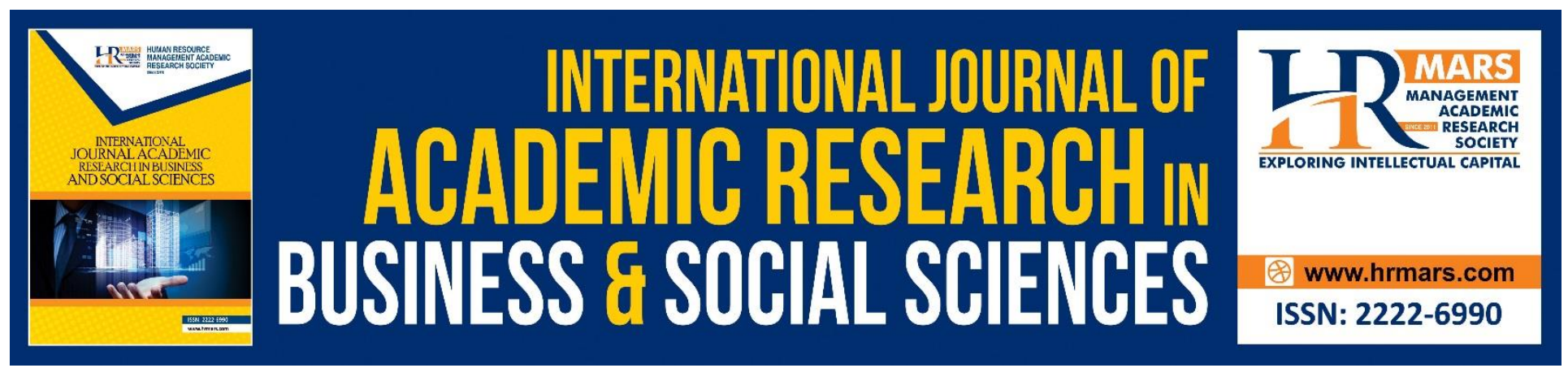

\title{
Using Pictures in Vocabulary Teaching for Low Proficiency Primary Pupils via PI-VOC
}

Ain Julia Mohamad Jazuli, Farah Farzana Mohammad Din, Melor Md Yunus

To Link this Article: http://dx.doi.org/10.6007/IJARBSS/v9-i1/5399 DOI: $10.6007 /$ IJARBSS/v9-i1/5399

Received: 19 Dec 2018, Revised: 14 Jan 2019, Accepted: 30 Jan 2019

Published Online: 01 Feb 2019

In-Text Citation: (Jazuli, Din, \& Yunus, 2019)

To Cite this Article: Jazuli, A. J. M., Din, F. F. M., \& Yunus, M. M. (2019). Using Pictures in Vocabulary Teaching for Low Proficiency Primary Pupils via PI-VOC. International Journal of Academic Research in Business and Social Sciences, 9(1), 311-319.

Copyright: (C) 2019 The Author(s)

Published by Human Resource Management Academic Research Society (www.hrmars.com)

This article is published under the Creative Commons Attribution (CC BY 4.0) license. Anyone may reproduce, distribute, translate and create derivative works of this article (for both commercial and non-commercial purposes), subject to full attribution to the original publication and authors. The full terms of this license may be seen at: $\underline{\text { http://creativecommons.org/licences/by/4.0/legalcode }}$

Vol. 9, No. 1, 2019, Pg. 311 - 319

http://hrmars.com/index.php/pages/detail/IJARBSS

JOURNAL HOMEPAGE

Full Terms \& Conditions of access and use can be found at http://hrmars.com/index.php/pages/detail/publication-ethics 


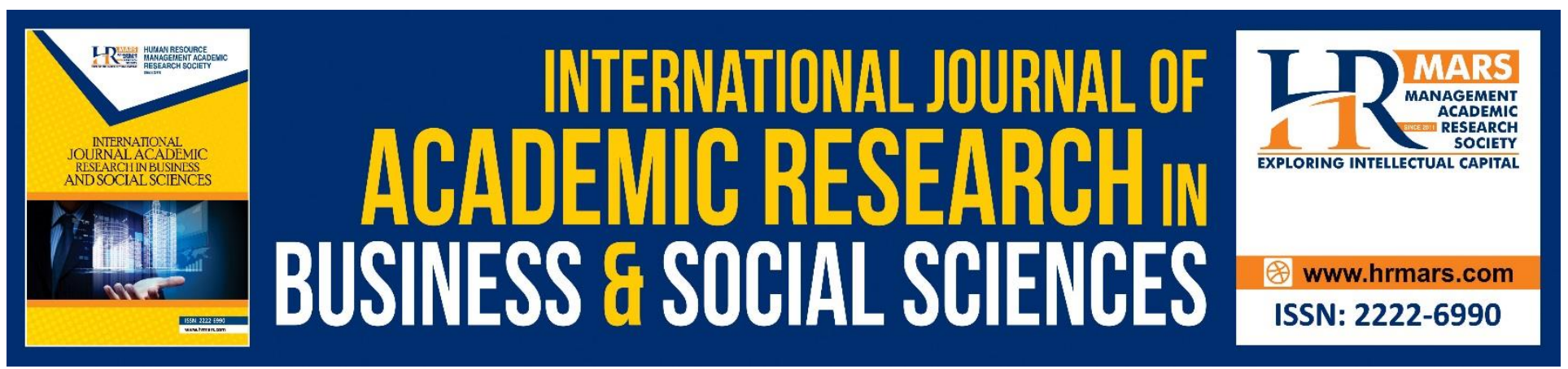

\title{
Using Pictures in Vocabulary Teaching for Low Proficiency Primary Pupils via PI-VOC
}

\author{
Ain Julia Mohamad Jazuli \\ Sekolah Kebangsaan Bachang, Melaka, Malaysia \\ Farah Farzana Mohammad Din \\ Sekolah Kebangsaan Bachang, Melaka, Malaysia \\ Melor Md Yunus \\ Universiti Kebangsaan Malaysia, Bangi, Malaysia
}

\begin{abstract}
In the lower primary Malaysian school context, vocabulary acquisition is a fundamental part of learning the second language and emphasized throughout the syllabus. Past studies proposed the use of pictures in learning new vocabulary help learners in meaning making and eventually ease them to comprehend what is read. Besides, it also assists the pupils to convey new information into their established knowledge scheme and increase their interest to learn. However, it was an inevitable truth that low proficiency learners had difficulty to acquire new vocabulary as they lack visualisation skill and if neglected they would lose interest in the learning process. This action research was conducted in an urban school in Melaka, Malaysia and involved 20 low proficiency Year 2 pupils. It emphasized the acquisition of 21 nouns and 7 verbs by using pictures (PI-VOC) related to a topic selected in CEFR Year 2 Topic 9 - At The Beach. This research was conducted with the help of document analysis and survey. A one group pre-test-post-test design was applied where the pupils' marks obtained were used as the indicator to determine their performance. The data gathered suggested that there was a significant improvement in pupils' vocabulary acquisition and they have higher motivation to learn with the help of PI-VOC. In conclusion, it is strongly recommended to use $\mathrm{PI}-\mathrm{VOC}$ in ESL classroom to teach vocabulary in teaching and learning process and should be used by all the teachers in their classrooms.
\end{abstract}

Keywords: Vocabulary Acquisition, Picture Assisted Learning, Interactive Game, Low Proficiency, Primary School 


\section{INTRODUCTION}

Throughout the centuries people are exposed to different cultures and because of this, they are prone to learn more than one language in order to communicate. English is Malaysia's second language and widely used by people of different age for various purposes since the colonial era of British. Nowadays, Malaysians have high interest on the acquisition of English because of its importance for borderless communication, educational development and for international or personal interaction. The rapid growth of technology and unlimited internet access act as contributing factors for the spread of English among the citizens. In addition, as stated by Yunus \& Thirusanku (2014), slowly, English became the mean of informal communication between the students. In order to compete internationally youngsters who study in the tertiary education have to learn by using sources and materials which mostly are in English. The society sees the need to master this language as employers consider the ability to use English is equally important to the first language when they recruit job applicants. Hence, the mastery of English is not to be taken lightly for its prominent roles in our daily life.

In Malaysia, the learning of English is made compulsory and generally the pupils will go through six years of primary and five years of secondary schooling Early studies done by researchers suggest that even after all the years and time spent, there is still a bunch of pupils who do not seem to be proficient in English (Musa, et al. 2012; Jalaludin, et al. 2008). This has influenced the Ministry of Education in Malaysia to look into this matter and make changes to improve the quality of English users in this country. Focusing on the teaching of English in primary classrooms, the Malaysian government has shown great interest in enhancing the pupils' proficiency level by revising the curriculum and syllabus in 2013. It accentuates $21^{\text {st }}$-century learning and suggests the pedagogical approach that meets pupils' multiple intelligences.

Acquiring English as a second language for young learners can be very challenging because of the intrinsic and extrinsic factors. Educators in schools should be aware of these so that they can design their lesson that maximise learners' potential in the mastery of the different skills in the language. According to the "Natural Order Hypothesis" by Stephan Krashen (1997), learners acquire language in a predictable order. In other words, learners will learn the easier function in grammar before the rest. For example, the mastery of meaning making or vocabulary acquisition is a prerequisite before the learners are able to make meaningful sentences or organise their ideas systematically. Consequently, the learning of new words is necessary in order to produce pupils with high English competency. Therefore, teachers in the primary classroom should pay attention to supporting vocabulary learning because it is a fundamental basis for higher language proficiency. The selection of materials by the teachers in learning vocabulary is vital because it can help pupils make the connection between the words and the meaning. Hence, this research was conducted to study two research questions which were:

1. How does PI-VOC be useful to help pupils' ability in vocabulary acquisition?

2. How effective is the use of PI-VOC towards vocabulary acquisition? 


\section{LITERATURE REVIEW \\ Vocabulary acquisition}

Children learn and acquire language in various contexts whether intentionally or not. Through their daily encounters with people, things or animals they will process the sounds or words and store them in their memory which eventually acts as a basis for further language development. In order to support vocabulary acquisition, a clear understanding of children's cognitive process is essential. Berk (2009) explained in her book that according to Piaget theory, children learning stages are invariant and universal. There are four stages involve; sensory motor stage, preoperational stage, concrete operational stage, and the formal operational stage. Focusing on early language learning, it is vital to creating a conducive environment for the children to study especially in the preoperational stage. Piaget further explained that there is a need to supply teaching aids like photographs, maps and also graphic organizers as to overcome children inability to visualise the real-world object. Apart from that, Vedyanto (2016) stated that it encouraged to promote comprehensible input for the pupils to learn new vocabularies to increase their language output. In other words, simplified input combines with pictures as learning aid can increase pupils' ability to make relation between the words learnt and the meaning in a real-life situation. Besides, by supporting the pupils' learning, it can reduce the hindrance to remembering words and allow better memorisation through repeated word-picture occurrence. Learning vocabulary is fundamental as a prerequisite to have better reading comprehension. In line with this, according to Misbah, Mohamad, Yunus and Ya'acob (2017), low level of word register is the cause for difficulty in acquiring other language skills.

In order to make the pupils' vocabulary learning more effective, teachers in school can teach them according to word families. Vocabulary fluency training can be supported by teaching the pupils according to word classes like noun, verb, pronoun, and others (Center, 2005). In the Malaysian context, as reported in PISA (2015), there is a significant deterioration of English proficiency that reflects our language quality level whereby we are at number 431 in reading comprehension as compared to other countries. Whereas, in another Malaysian based study it is reported that even after all the years and time spent in school with various English programmes, youngsters still showed a low level of competency (Musa, Lie, \& Azman, 2012; Jalaludin, Awal, \& Bakar, 2008) which eventually will affect them in the job market. This wonders the ministry and teachers in schools. Somethings need to be done to overcome this dilemma which will increase the level of English competency among Malaysians.

\section{Picture Assisted Learning}

Learning English as a second language (ESL) can be very challenging as learners may not have adequate word register to make meaning and produce sentences to deliver the intended message. ESL learners have a high dependency on vocabulary knowledge and the mastery of words is important because language is based on words (Thonbury, 2002). Picture assisted learning is one of the solutions to support vocabulary acquisition, especially for slow learners. Using pictures enable learners to make the connection between their prior knowledge and the new vocabularies that they want to learn. This is in line with the research done by Pan and Yi-Ching (2009), who found out that the integration of picture assisted learning became the pupils' preference as it helps them to understand better. In addition, teachers will be able to engage the learners closely with the literal 
text even when the students have low knowledge in English (Yunus, Salehi \& John; 2014). Colourful graphics and interesting pictures help them to make the word more memorable. Moreover, those pictures can increase pupils' motivation in learning as they are attracted to the visual aids. Visual representation of the words may help pupils in making meaning and process the information. It is indeed necessary to provide pictures to learn new vocabularies, especially for slow learners. As suggested by Thornbury (2002), providing suitable learning aids in language acquisition hinders the pupils from getting frustrated because of their inability to make connection between the words taught with the real intended meaning. Apart from providing pictures, teachers can increase the pupils' motivation in learning English by embedding $21^{\text {st }}$-century learning in the lesson like using interactive computer-based activity.

\section{Interactive Game}

The activities that the teachers use in their lesson have a great influence in determining the output that the pupils will produce. This is in line with the research done by Cheng, Yunus \& Mohamad (2016), saying that although the learning of English starts at home, the teacher plays a vital role in creating English rich environment. Attention-grabbing, interesting and yet meaningful lessons should be a fundamental element for teachers to instil in their lessons so that pupils can learn in a fun environment. Pupils are more interested to learn new vocabulary when there is a healthy competition like when they are engaged in an interactive language game. This is supported by Center (2005) where pupils will become highly motivated when the teachers create an interesting game-like activity in the class. The pupils' interest will boost up with the integration of technology. Apart from assisting pupils' understanding of the language content, digital game activities that involve computer will enhance their motivation (Lee \& Hammer, 2011).

In Malaysia, the government has equipped the schools with facilities such as computers, internet connection, and trained teachers to support this $21^{\text {st }}$-century learning. Children today are exposed to digital devices and it is an inevitable truth that they are more attracted to colourful, fun and interactive games. Therefore, it would be great if teachers in school integrate this into their lesson to provide enjoyable and informative lessons. This is proven in a Malaysian based study whereby the use of technology will boost pupils' engagement which enhances their learning process (Yunus, Nordin, Salehi, Embi \& Salehi, 2013b) as the ministry has supplied sufficient support. Looking from the teachers' point of view, the use of interactive game through technology will ease them in promoting language acquisition (Yunus, Nordin, Salehi, Choo \& Embi, 2013a). Thus, by integrating interactive game and the use of technology it will benefit both the teachers and the students.

\section{Methodology}

This qualitative research was carried out in three sessions within 5 weeks in reference to Kemmis and Mc Taggart's Action Research Spiral Model. For the first session, the samples did a pretest based on the given worksheets. In the next 4 weeks, the samples went through an intervention programme where they learnt new vocabularies using PI-VOC. PI-VOC is the learning of vocabulary through the use of pictures in a form of digital flashcards. At the end of the intervention pupils were exposed to 7 verbs and 21 nouns. Pupils answered questions in an interactive English game such as Quizziz through their personal virtual learning account (VLE Frog). After going through the 
intervention, at the last session, samples did a post-test as to see their improvement after going through the intervention. Then, the samples answered questions related to the process of learning and also regarding the activities that had been done in an 8 items survey. The reason for this is to evaluate if the data gathered is valid and concrete.

The main data was collected based on the marks recorded when the pupils answered worksheets during the pre and post intervention. An 8 items survey was done where the pupils answered "Yes or No" scale that reflects their feeling learning vocabulary with and without using $\mathrm{PI}$ VOC.

\section{Research Participants}

The participants for this research were 20 pupils from a Year 2 classroom. For this research, the subjects come from above average homes and most of them have problems expressing themselves in English. The usage of English at home and school is very low and they prefer to use their mother tongue which is Malay. Therefore, taking into consideration the students' background and the limited exposure to the English language, this appears to be the hardest subject for them. Hence, the students are reluctant to use English when they were asked to do so. The reason being, they are not confident to speak in English as they lack in vocabulary. When asked, the general response was that reading was the hardest skill to master compared to the other skills and the most stressful activity.

\section{Findings and discussions}

After the intervention had been implemented, the results were gathered. In order to study the status of each factor in the research, dependent T-Test was used to answer the first research question which is:

1. How does PI-VOC be useful to help pupils' ability in vocabulary acquisition?

Dependent T-Test functions to determine significant differences between the mean of a variable and the test value. Test value will act as a midpoint which has a fixed value, 0.05 . If the test value is less than 0.05 , the status of the component will be positive. If not, the studied variable will not suitable in terms of the target population. This study has found out that there is a significance differences between the pre and post-test marks when pupils learnt using PI-VOC for the samples with $(t(19)=-12.704 ; p=0.000[95 \% C l=-3.378$ to -2.422$]$.

Table 1: Pre and Post-test results

\begin{tabular}{cccccc}
\hline & Mean & $\mathrm{t}$ & $\mathrm{df}$ & Sig. (2-tailed) \\
\hline Pair 1 & Pre - Post & 2.90 & -12.70 & 19 & .000 \\
\hline
\end{tabular}

In addition, as to answer the second research question, a survey was conducted to find out their motivation level in learning vocabularies using PI-VOC. The result of the survey is recorded in Table 2. 
INTERNATIONAL JOURNAL OF ACADEMIC RESEARCH IN BUSINESS AND SOCIAL SCIENCES

Vol. 9, No. 1, Jan, 2019, E-ISSN: 2222-6990 @ 2019 HRMARS

Table 2 : PI-VOC Survey Results

\begin{tabular}{llcc}
\hline \multicolumn{1}{c}{ Items } & \multicolumn{1}{c}{ Questions } & $\begin{array}{c}\text { Yes } \\
\text { (No. of pupils) }\end{array}$ & $\begin{array}{c}\text { No } \\
\text { (No. of pupils) }\end{array}$ \\
\hline 1. & I use English at home & 5 & 15 \\
2. & I use English at school & 2 & 18 \\
3. & I like to learn new words & 10 & 10 \\
4. & I like to learn new words with PI-VOC & 18 & 2 \\
5. & I understand the new words when learning & 18 & 2 \\
& using PI-VOC & & 1 \\
6. & I want to learn using PI-VOC & 19 & 1 \\
7. & I can remember words easily & 11 & 9 \\
8. & I can remember words when learning using PI- & 19 & 1 \\
& $\quad$ VOC & & \\
\hline
\end{tabular}

Based on Table 2, it can be concluded that PI-VOC played an important role in the process of teaching and learning of vocabulary. This is because, based on the survey, the samples claimed that they were able to understand and remember the new words better when they learnt the words with PI-VOC. Moreover, the survey also informed the researchers that the pupils are keen and motivated to learn new words by using PI-VOC in the future.

In compare to the beginning of this research, some of the samples were not able to comprehend the words and pictures that they have learnt. They could write the phrase more accurately and confidently after using the PI-VOC technique. The findings show that the participants managed to spell and write the selected phrase correctly using the PI-VOC. Hence, from this, it shows that pupils learn better through pictures and repetitions. The reason being, after they learnt using the PI-VOC, the pupils needed to complete the quiz given to them through Quizziz which help them to recall the words that they have learnt.

\section{Conclusion}

The increment in the samples' marks after the intervention period suggests that PI-VOC can assist them in vocabulary acquisition and increase their motivation especially for low proficiency learners. All the data collected during the intervention has shown that the pupils were interested and happy in using PI-VOC as one of the ways to improve their spelling.

Moreover, with PI-VOC, samples were motivated and had high interest in learning new vocabularies. The result from this research is in line with previous studies that encourage the use of pictures in ESL classrooms. Such an important result can be used by teachers in integrating PI-VOC in their teaching and learning process. Policy makers can include this in the curriculum design and encourage teachers to use it as a tool to support vocabulary acquisition. Learning vocabulary by using pictures contributes to higher motivation because the learners can relate closely with the literal text even when the students have low knowledge in English (Yunus, Salehi \& John; 2014). Though some responded they are not interested in using PI-VOC and don't think it can help them, PI-VOC is not the sole solution to help low proficiency learners. Teachers may adapt and adopt PI-VOC to suit their pupils' need in their lessons. Although the overall results of this study suggest PI-VOC helps low 
INTERNATIONAL JOURNAL OF ACADEMIC RESEARCH IN BUSINESS AND SOCIAL SCIENCES

Vol. 9, No. 1, Jan, 2019, E-ISSN: 2222-6990 (C) 2019 HRMARS

proficiency learners in vocabulary acquisition, a bigger sample should be considered in the future study.

\section{References}

Berk, L. E. (2009). Child Development. United States of America: Pearson.

Center, Y. (2005). Beginning Reading. Australia: Griffin Press.

Cheng, L., Yunus,M.M., Mohamad, M. (2016). Issues Contributing to Low Performance of English in a National School in Song, Sarawak. International Seminar on Generating Knowledge Through Research, 499 - 510

Jalaludin, N. H., Awal, N. M., \& Bakar, K. A. (2008). The mastery of English language among lower secondary students in Malaysia: A linguistic analysis. European Journal of Social Sciences, 106119.

Lee, J. J., \& Hammer, J. (2011). Gamification in education: what, how, why bother? Definitions and uses. Exchange Organizational Behavior Teaching Journal, 15(2), 1

Ministry of Education (2010). Preliminary report: Malaysia Educational Blueprint 2012-2025, Ministry of Education, Kuala Lumpur, Malaysia.

Misbah, N.H., Mohamad, M., Yunus,M. M. \& Ya'acob, A. (2017). Identifying the Factors Contributiong to Students' Difficulties in the English Language Learning. Scientific Research, Vol. 8 (13).

Musa, N. C., Lie, K. Y., \& Azman, H. (2012, January). Exploring English Language Learning and Teaching in Malaysia. GEMA Online Journal of Language Studies, 35-51.

Pan, Y., and Yi-Ching, P. (2009). The Effects of Pictures on the Reading Comprehension of LowProficiency Taiwanese English Foreign Language College Students: An Action Research Study. [Online] Available: http://tapchi.vnu.edu.vn/nn_3_09/b.8.pdf (September 06, 2012).

PISA. (2015). PISA 2015 Results. OECD. Retrieved from http://www.oecd.org/pisa/

Thirusanku, J. \& Yunus, M.M. (2014). Status of English in Malaysia. Asian Sosial Science Canadian Center of Science and Education; Vol. 10 (14)

Thornbury, S. (2002). How to Teach Vocabulary. Harlow: Pearson Education Limited.

Vedyanto. (2016). Correlation between picture use in test format and students' vocabulary achievement. Australian in Language and Literary studies, 54

Yunus, M.M., Salehi, H., John, D.S.A. (2014) Using Visual Aids as a Motivational Tool in Enhancing Students' Interest in Reading Literary Texts. Recent Advances in Educational Technologies. 
INTERNATIONAL JOURNAL OF ACADEMIC RESEARCH IN BUSINESS AND SOCIAL SCIENCES

Vol. 9, No. 1, Jan, 2019, E-ISSN: 2222-6990 @ 2019 HRMARS

Yunus, M.M, Nordin, N., Salehi, H, Embi,M.A., Salehi, Z. (2013b) . The Use of Information and Communication Technology ICT in Teaching ESL Writing Skills. English Language Teaching; Vol. 6 (7).

Yunus, M.M., Nordin, N., Salehi, H., Choo, H.S., Embi, M.A. (2013a). Pros and Cons of Using ICT in Teaching ESL Reading and Writing. International Education Studies; Vol. 6(7). 